\title{
Chapter I.11
}

\section{ENVIRONMENTAL PROBLEMS IN GYPSUM KARST TERRAINS Alexander Klimchouk \& Vjacheslav Andrejchuk}

\section{Introduction}

Karst terrains are inherently vulnerable, as they are characterized by highly inhomogeneous permeabilities, complex underground drainage systems, the ability to transmit fluids and pollutants easily, and a susceptibility to surface collapse and subsidence. Karst areas commonly pose numerous and severe environmental problems and hazards. Human practices and management procedures, developed for most normal terrains, may enhance these problems dramatically when applied to karst terrains.

Over the past few decades the specific and fragile nature of karst systems has become increasingly well understood scientifically, and much attention has been focused upon the methodology and practices of karst resource protection and hazard assessment. However, the vast majority of studies have been focused specifically upon carbonate karst. The exception was in the former Soviet Union, where the extensive area covered by gypsum karst, and its associated severe problems (commonly enhanced by bad management practices), forced investigators to pay particular attention to the special characteristics of gypsum karst terrains. The last decade, however, has been marked by an explosive increase in interest specifically in gypsum karst, driven by the needs of expanding and "deepening" economic activities, in many countries throughout Europe, North America and Asia, particularly in Germany, England, France, Spain, the United States and Canada.

Environmental problems and hazards induced by gypsum karst have been more clearly recognized by engineering geologists than by karstologists. The reasons are twofold: 1) there has been a generally poor recognition of gypsum karst as a "true" karst among mainstream karstologists (see Chapter I.4) and, 2) compared to carbonate karst, areas of exposed gypsum karst are small, and the wide development of deep-seated intrastratal gypsum karst has been poorly appreciated within the predominant "geomorphological" paradigm of karstology. Engineering geologists commonly deal with gypsum karst hazards. However, they tend to treat such hazards as local dissolution or "leaching" effects, without recognizing the full nature and structure of karst systems, the principles of their evolution and their detailed behavior.

Most of the environmental problems and hazards characteristic of carbonate karst are also found commonly gypsum karst terrains. However, the more rapid dynamics of gypsum karstification and some of the geological peculiarities of evaporitic rock formations result in associated problems and hazards commonly being even more severe than their equivalents in carbonate karsts. Gypsum karst is also much more susceptible to human impacts, particularly if changes in groundwater circulation are induced.

The present paper is not intended to provide a comprehensive consideration of all recorded environmental problems associated with gypsum karst. In order to draw attention towards specific 
areas of concern, it concentrates upon noting some of the effects related to human impacts that are unique to karst systems in gypsum or most commonly occurring, and reviews some representative examples.

\section{Some characteristics specific to gypsum karst systems}

The main differences between karst development in gypsum and in carbonate rocks lie in their dissolution chemistry and kinetics, and in various geological peculiarities of the respective rocks and formations. Solubility and dissolution rates of gypsum are much greater than those of carbonates. Under suitable hydrogeological conditions, substantial dissolutional growth of conduits and cavities can take place within a few years in gypsum, while in carbonate karst rates of void enlargement can rarely achieve significance within the human life or construction industry time scales. From the civil engineering viewpoint, gypsum is by far the most problematical of the naturally occurring foundation materials. It has been pointed out (James, 1992, p.235). that gypsum "...has an 'awkward' solubility; neither so high as to be easily washed from surface dê̄osits nor so low as to be unaffected in foundations".

Carbonate and gypsum karsts both occur most commonly in intrastratal settings, where karstifiable units lie beneath some thickness of cover beds, which may be poorly consolidated. From the point of view of many human practices, such settings can present more problems then are presented by exposed karst settings. Also, intrastratal karst terrains are, in general, much more heavily populated and industrialized than are areas of exposed karst, and this imposes far greater human impacts. Against this background, intrastratal gypsum karst terrains are less stable, more prone to subsidence and collapse phenomena and more vulnerable to changes induced by human activities, than are analogous regions of carbonate karst. Examples of the dramatic acceleration of karst processes in a response to anthropogenic changes, with consequently catastrophic results, are numerous in gypsum karst regions. A final factor that should not be overlooked is that the depth at which intrastratal karstification can affect the surface through collapse is generally far greater in gypsum karst than in carbonate karst terrains.

\section{Water resources}

Resources of underground water associated with gypsiferous formations are commonly quite large, although their use is relatively limited because their quality is only fair to poor due to their high content of sulphates. Substantial sulphates concentrations are also generally present in waters stored within adjacent aquifers that are connected hydraulically to gypsiferous aquifers. Waters in gypsum karst terrains commonly contain over $1,000 \mathrm{mg} / \mathrm{L}$ (locally more than 2,000 $\mathrm{mg} / \mathrm{L}$ ) of sulphates, which makes them unsuitable for use as domestic water supplies. Much higher concentrations are not uncommon where gypsum karstification is accompanied by dissolution of the various other salts that are associated with evaporitic sedimentary formations. However, underground water sources are exploited widely for industrial and agricultural needs in many areas where other water resources are scarce. This practice is commonplace in many parts of the USA (including Oklahoma, Texas and New Mexico), Spain, Germany, the Baltic Republics, 
the Western Ukraine, Russia, Libya, Iraq, China and elsewhere.

\section{Pollution}

Gypsum karst systems are susceptible to pollution in much the same way as carbonate karst, especially in situations that include superficial recharge. This is a reflection of commonly welldeveloped point recharge systems (especially characteristic of intrastratal karst), reduced self-purification capabilities and rapid rates of conduit flow. There are few aspects relating to the pollution susceptibility of gypsum karst that are not also applicable to carbonate karst. Several examples of different kinds of pollution documented in typical gypsum karst areas are described below.

\subsection{Pollution by oil}

In the Kungursky area of the Pre-Urals (Russia) oil is produced from the thick Artinsky limestone sequence, which is overlain by evaporitic (gypsum, anhydrite and dolomite) and terrigenous (sandstone and argillite) rocks. In the course of production, transportation and processing, spillage is common due to poor technological standards and management. During such accidents, large quantities of oil have been spilled into dolines with ponors; sometimes this has been done intentionally, in order to "reduce" the visually impact of the losses. Some dolines with plugged, or partially plugged, bottoms became oil lakes, and the karst aquifer can become severely polluted by oil. Areas of polluted groundwater (including karstic groundwaters - within areas of gypsum karst) are shown in Fig.1.

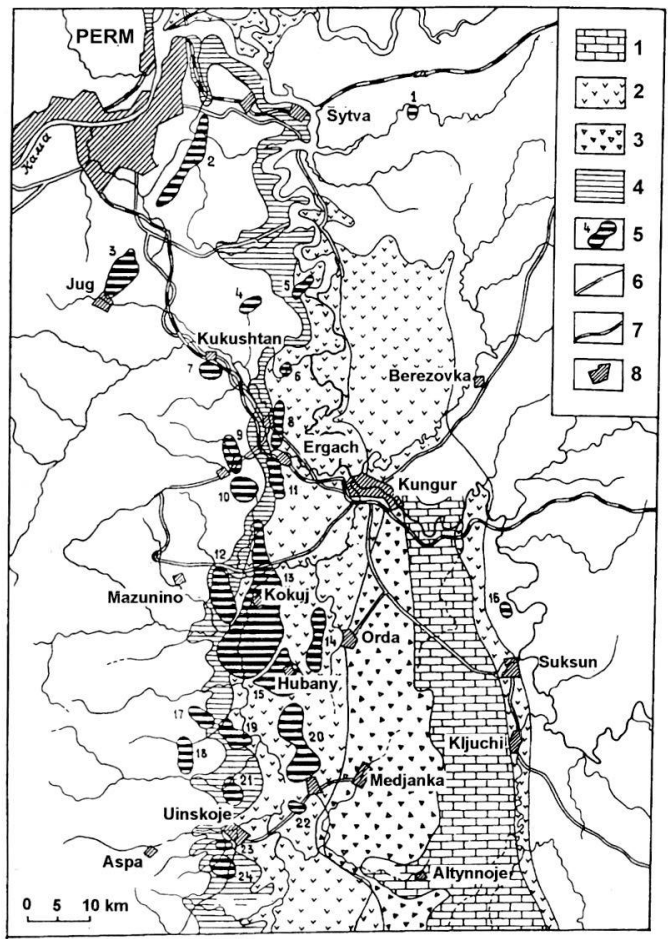

Fig. 1. Areas of oil pollution in the karst areas of the Pre-Urals. Areas:

$1=$ of carbonate karst,

$2=$ of denuded gypsum karst,

$3=$ of karst breccias,

$4=$ of intrastratal entrenched and subjacent gypsum karst,

$5=$ of groundwaters polluted by oil;

$6=$ roads,

$7=$ railroads,

$8=$ settlements. 
Well-developed karst permeability and the physical and chemical characteristics of the pollutant determine a very slow rate of self-purification of the groundwaters. In "favourable" conditions oil has accumulated in karst reservoirs in such quantities that the possibility of developing such "secondary" oil reserves has been put under evaluation. The problem of pollution of karst waters by oil is of regional extent in the Pre-Ural region.

\subsection{Radioactive pollution}

After the Chernobyl accident radioactive fallout produced a pattern of pollution in some localized areas, even at a significant distance from Chernobyl. One such polluted "island" is an area in the north-west of the Chernovitsky region in the Western Ukraine, some $500 \mathrm{~km}$ from Chernobyl. Levels of radioactive pollution at the surface remain as high as $30-40 \mu \mathrm{R} / \mathrm{h}$, even 10 years after the accident. Study of the distribution of radioactivity has revealed that the local presence of karst landscapes is one of the major factors controlling the differentiation of radioactive pollution through the area.

Accumulation of radionucleides is favoured by a high content of carbonates and organic matter in soils. Relief plays an important role, causing radionucleides to be washed high ground and transported towards relatively lower points, particularly into dolines. However, dolines accumulate radionucleides only if their bottoms are plugged by loose material (Fig. 2-B). Radioactivity levels increase from doline edges to their floors, where they reach the maximum values recorded for the area $(60-70 \mu \mathrm{R} / \mathrm{h})$. At the lips and on the slopes of dolines the radioactivity levels are lower (20-25
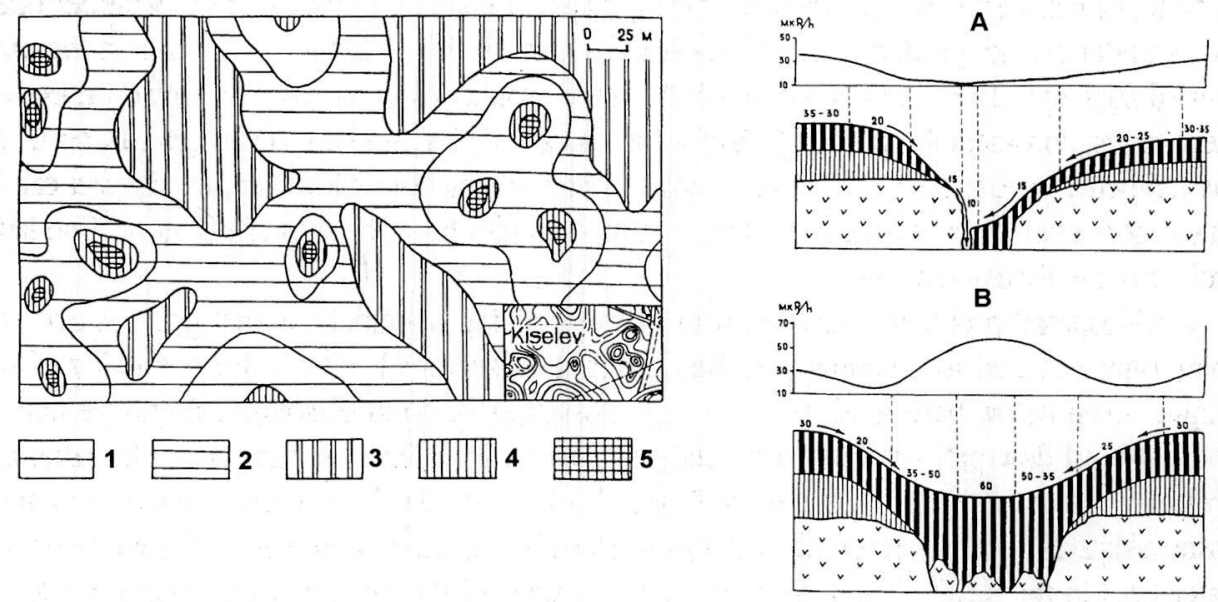

IIIII.

Fig.2. Distribution of radioactive pollution through an area of gypsum karst in the Western Ukraine. Left: part of the map of surface radioactivity. Values in $\mu \mathrm{R} / \mathrm{h}: 1=21-25,2=26-30,3=31-35,4=36-50,5=51-65$. Right: characteristic distribution of surface radioactivity across dolines: $\mathrm{A}=$ with an open ponor, $\mathrm{B}=$ with plugged bottom. $1=$ soil, $2=$ loam and clay, $3=$ gypsum, $4=$ radioactivity levels $(\mu \mathrm{R} / \mathrm{h}), 5=$ surface runoff. 
$\mu \mathrm{R} / \mathrm{h}$ ) than the regional background. In contrast, dolines that contain sink points (ponors) demonstrate the lowest values at their bases (Fig.2-A), 10-20 $\mu \mathrm{R} / \mathrm{h}$, which is comparable with the regional background levels before the Chernobyl accident. Distribution of radioactivity throughout the area reflects the action of these two mechanisms (Fig.2-left).

\subsection{Pollution by fertilizers}

Many regions of intrastratal gypsum karst throughout Germany, the Baltic Republics, Ukraine, Russia and other countries are dominantly agricultural. Wide and locally intensive use of agricultural chemicals leads to pollution of karst waters by organic and mineral fertilizers and pesticides. Heavy pollution of a gypsum karst aquifer by nitrogen and organic compounds in Lithuania and Latvia is reported by Paukstys \& Narbutas (Chapter II.10). Significant concentrations of pesticides have been measured in the waters of cave lakes, and in clay fillings, in Optimisticheskaja, Ozernaja and Zolushka caves in the Western Ukraine (Andrajchuk \& Klimchouk, 1993). In the Western Ukraine pollution of karst aquifers by fertilizers is commonly enhanced by the effects of land reclamation measures (soil water drainage), where many soil drainage pipes are routed into dolines with sinking ponors.

\section{Mining activity}

Gypsum karst has a considerable influence upon the conditions of mining operations and, in turn, mining commonly produces a strong impact on gypsum karst.

Gypsum itself is a commodity that is mined heavily in many countries (including Russia, Ukraine, China, Germany, Canada, USA, Spain, Italy and France). Gypsum mines, whether opencut or underground, produce generally localized impacts if the operation takes place in the unsaturated zone and does is not accompanied by underground water abstraction. However, even in these cases, considerable damage to landscape characteristics and cave resources can occur (as has happened in Germany, Italy and Spain). If water abstraction is involved, the impact can be much more complex and severe, as illustrated by examples from the Western Ukraine. The latter problems are discussed below.

A widespread problem associated with gypsum mining operations is that gypsum beds are commonly assumed to be aquifuges. This assumption seemingly allows the possibility of safe mining, even below base level. However, the possibility of rapid dissolutional enlargement of underground flow paths is frequently underestimated. Flooding experienced at the Izhemsky gypsum mine in the Timansky region of Russia clearly illustrates the relevant dangers (Lysenin \& Sosnovskaja, 1974). Underground workings in Devonian gypsum were some $20-35 \mathrm{~m}$ below the water level in the nearby Izhma river. At the initial stage of the operation water inflows into the workings were negligible, but they reached $1,700 \mathrm{~m}^{3} /$ day in 1959 and increased to $20,000 \mathrm{~m}^{3} /$ day in 1965. This inflow developed due to piracy of water from the surface river and eventually necessitated abandonment of the mine. Numerous collapses formed at the surface between the mine area and river during the last few years of the operation and its associated intense water abstraction. The total water withdrawal in 1961-1965 amounted to $8,820,000 \mathrm{~m}^{3}$, and the related dissolutional removal of gypsum was estimated at 11,500 tons or $5,000 \mathrm{~m}^{3}$. 
Some commonly mined mineral commodities (such as salts) are found associated with evaporite formations, or with gypsum that has formed due to epigenetic processes (such as native sulphur). Extraction of salt by the underground leaching method commonly induces collapse and subsidence processes in the overlying gypsiferous strata, disrupting their integrity and greatly enhancing gypsum karst development. Such cases are known from the Donetzk region in the Ukraine and the pre-Caspian region in Russia. Epigenetic sulphur deposits associated with gypsum are most extensively mined in the pre-Carpathian region of the Western Ukraine and Poland, and in New Mexico and Texas in the United States.

Finally, mining of various materials that occur in the strata that overlie or underlie gypsiferous formations can be severely complicated by the presence of gypsum karst and can commonly result in its activation. In the Western Ukraine, clays overlying the gypsum bed are mined for the cement industry. This activity is greatly complicated by the subsequent activation of karst processes in the confined gypsum aquifer below, resulting in massive inrushes of water, and collapses. In the Shanxi coalfield of China, mining is severely complicated by the presence of vertical through structures (VTS; see Chapter I.10 for discussion of their general characteristics) that are related to gypsum karst in the deep-seated Ordovician Fengfeng Formation (Yaoru \& Cooper, 1997; Chapter II.14 in this volume). The VTS serve either as conduits, allowing surface and overlying groundwater to enter the mine workings, or as paths along which underlying confined carbonate aquifers can discharge upwards. Some of the largest inrushes of water recorded in Chinese mines were related to the latter situation. For example, a VTS intercepted by a mine at the depth over $300 \mathrm{~m}$ discharged up to $12 \mathrm{~m}^{3} / \mathrm{s}$ to flood the mine, yielding about $46 \mathrm{~km}^{3}$ of water (Chapter II.13).

In all cases, backward and forward impacts between mining operations and gypsum karst are at their greatest where the mining has a significant effect upon the architecture of underground water circulation, and is accompanied by water abstraction. This issue is discussed further below.

\section{Underground water abstraction}

Abstraction of groundwater from gypsum karst aquifers, or from aquifers adjacent to them, for water supply, or during the course of mining operations, commonly causes a very marked impact on karst development in gypsum. Increased hydraulic gradients determine an increase in flow velocities and dissolution rates, which can sometimes result in a dramatic intensification of karst processes. Well-documented examples from the Western Ukraine illustrate the possible consequences.

Owing to differential uplift during the Late Pliocene to Pleistocene and the consequent deep incision of major valleys, the current settings of karst development vary between three sub-parallel zones. These represent respectively the deep-seated (confined), subjacent and entrenched subtypes of intrastratal karst (see Chapter II.9 for details). Within the zone of entrenched karst the gypsum is fully drained and quarrying does not create many problems.

The Kryvsky gypsum quarry lies on the border between Moldova and the Ukraine, in an area where, during the pre-quarrying period, the water table was established within the upper part of a $30 \mathrm{~m}$-thick gypsum bed, just 1-2m below its upper surface (subjacent karst setting). The gypsum 


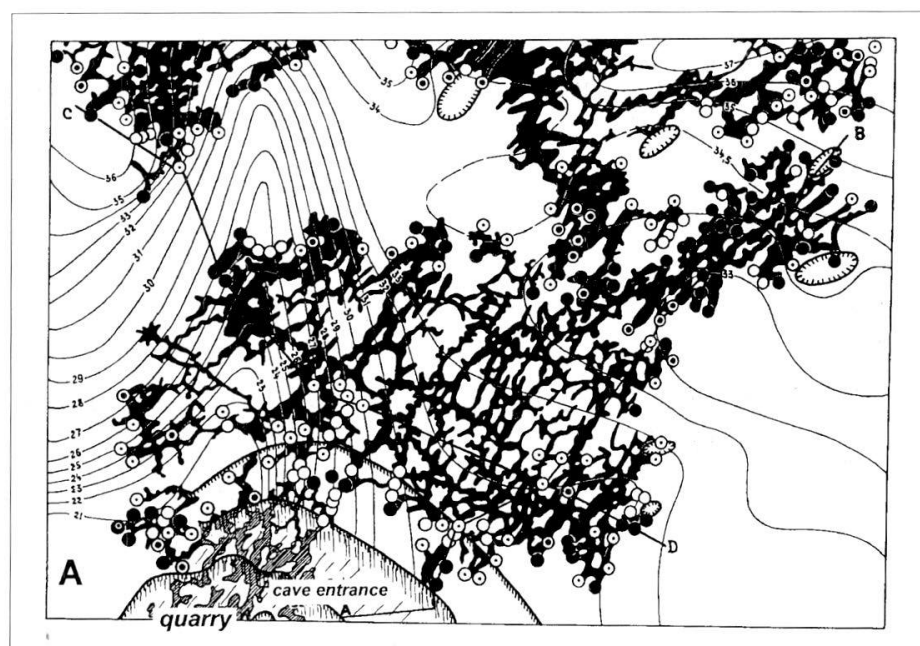

Fig. 3. Distribution of breakdowns (VTS) within the area of Zolushka Cave in the vicinity of Kryvsky quarry, Western Ukraine (After Andrejchuk \& Klimchouk, 1993). $A=$ plan, $B=$ profiles. Circles of different styles indicate various stages of upward propagation of VTS.

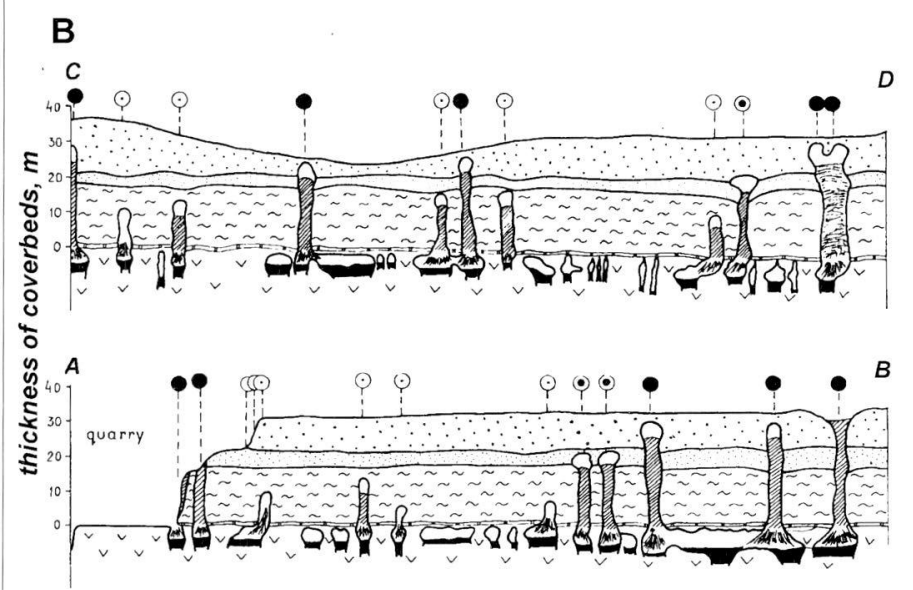

aquifer is connected hydraulically with an underlying sandy-carbonate aquifer. Forty-years of quarrying and associated water abstraction have led to a $15-25 \mathrm{~m}$ lowering of the water table, resulting in that the upper storey of a huge maze cave system becoming accessible (Zolushka Cave; $92 \mathrm{~km}$ of passages are surveyed to date). The drawdown cone in the potentiometric surface has expanded to cover an area of $400 \mathrm{~km}^{2}$. There is also a lower storey to the cave, still water-filled, and connected to the upper level by vertical pits.

De-watering of the cave system has been accompanied by drastic changes of hydrochemical conditions within the aquifer, resulting in deposition of large quantities of iron and manganese hydroxides (Volkov et al., 1987; Andrajchouk \& Klimchouk, 1993). Also, desiccation of clay fill in the cave and continuing water circulation at lower level have caused a reduction in the volume of cave sediments and triggered many subsidences inside the cave. Previously formed breakdowns have been re-activated due to subsidence of underlying material. Vertical solution pipes have developed in the extended vadose zone, causing new breakdowns to take place due to upward 
stoping (see Chapter I.10). The distribution of breakdowns throughout the cave area in the vicinity of the quarry is shown in Fig. 3. Survey of the breakdown talus in the cave has allowed its classification according to age, relative to the start of quarry operations. Of a total of 405 breakdowns, $24.4 \%$ are classified as natural and pre-technological, $16.3 \%$ as pre-technological but re-activated during the modern stage, and $60.3 \%$ are entirely recent, having formed in the last $35-40$ years of quarry operation.

Even more severe consequences, in terms of underground water abstraction and the induced intensification of karst processes, occurs if quarrying breaches artesian confinement. In the zone where artesian hydrogeological settings still predominate, sulphur ores (at the top of the gypsum bed) and overlying clays for cement industry are mined extensively by open pits. These operations are exemplified respectively by the Jazovsky sulphur quarry (Fig.4) and by the Nikolaevsky clay quarry; both breaching the thickness of the confining clay. Such quarrying schemes had been based on the widespread but misguided belief among local geologists that the gypsum is an aquiclude that would prevent hydraulic connection of the underlying regional aquifer with the quarried sequences above the gypsum. In reality, pre-existing artesian cave systems within the gypsum provide a highly efficient hydraulic connection through the bed (Klimchouk, 1997), and this has caused major problems for the mining operations.

Water withdrawal from both the Jazovsky and Nikolaevsky quarries has been increasing dramatically during the initial period of the operations, reaching respectively 100,000 and $280,000 \mathrm{~m}^{3} /$ day. The following consequences have occurred in groundwater circulation (Andrajchouk \& Klimchouk, 1993):

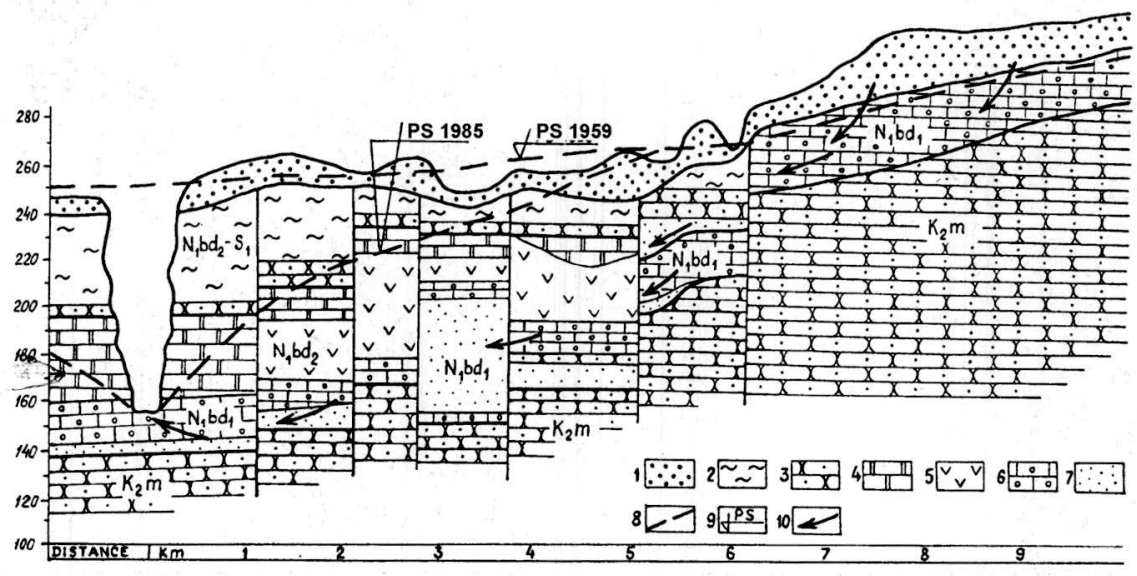

Fig.4. Geological-hydrogeological profile of the Jazovsky sulphur deposit area (After Andrajchouk \& Klimchouk, 1993). 1 = Quaternary sediments (sands), 2 = clays, $3=$ sandstones, $4=$ epigenetic sulphurbearing limestones, $5=$ gypsum, $6=$ bioherm limestones, $7=$ sands, $8-9=$ potentiometric surface for different years, $10=$ directions of underground water flow. 
1. Potentiometric surfaces have fallen dozens of meters (up to $90 \mathrm{~m}$ at the Jazovsky site; see Fig.4) and hydraulic gradients have increased drastically.

2. Local areas of upward flow in pre-existing groundwater systems have been reversed into zones of downward recharge; piracy of surface runoff has occurred. Pirated surface stream water comprises up to $25 \%$ of the total withdrawal from the main open-cut mine in the Jazovsky deposit (Ivanov et al, 1985), and the Zubra river, the course of which lay a few kilometres from the Nikolaevsky quarry, has lost almost all of its flow.

3. Extensive drawdown cones have formed in the potentiometric surface, affecting an area of up to $100 \mathrm{~km}^{2}$ at the Jazovsky deposit.

4. Velocities of underground water flow have increased significantly, being up to $2.5 \mathrm{~km} /$ day near the Jazovsky deposit and up to $10.2 \mathrm{~km}$ /day near the Nikolaevsky deposit.

As a result of the sharply accelerated circulation involving both surface waters and waters from the underlying aquifer, rates of gypsum dissolution and of cavity enlargement have increased dramatically. Dissolution rates in the region, variously estimated by hydrological-hydrochemical and standard-tablet techniques, are normally about $0.2-0.4 \mathrm{mg} \mathrm{day}^{-1} \mathrm{~cm}^{-2}$ under the natural conditions of this zone. They have increased to $1.6 \mathrm{mg} \mathrm{day}^{-1} \mathrm{~cm}^{-2}$ in the Jazovsky deposit and are as high as $28.2 \mathrm{mg}$ day-1 $\mathrm{cm}^{-2}$ in the Nikolaevsky deposit' due to the effects of the above factors (Klimchouk
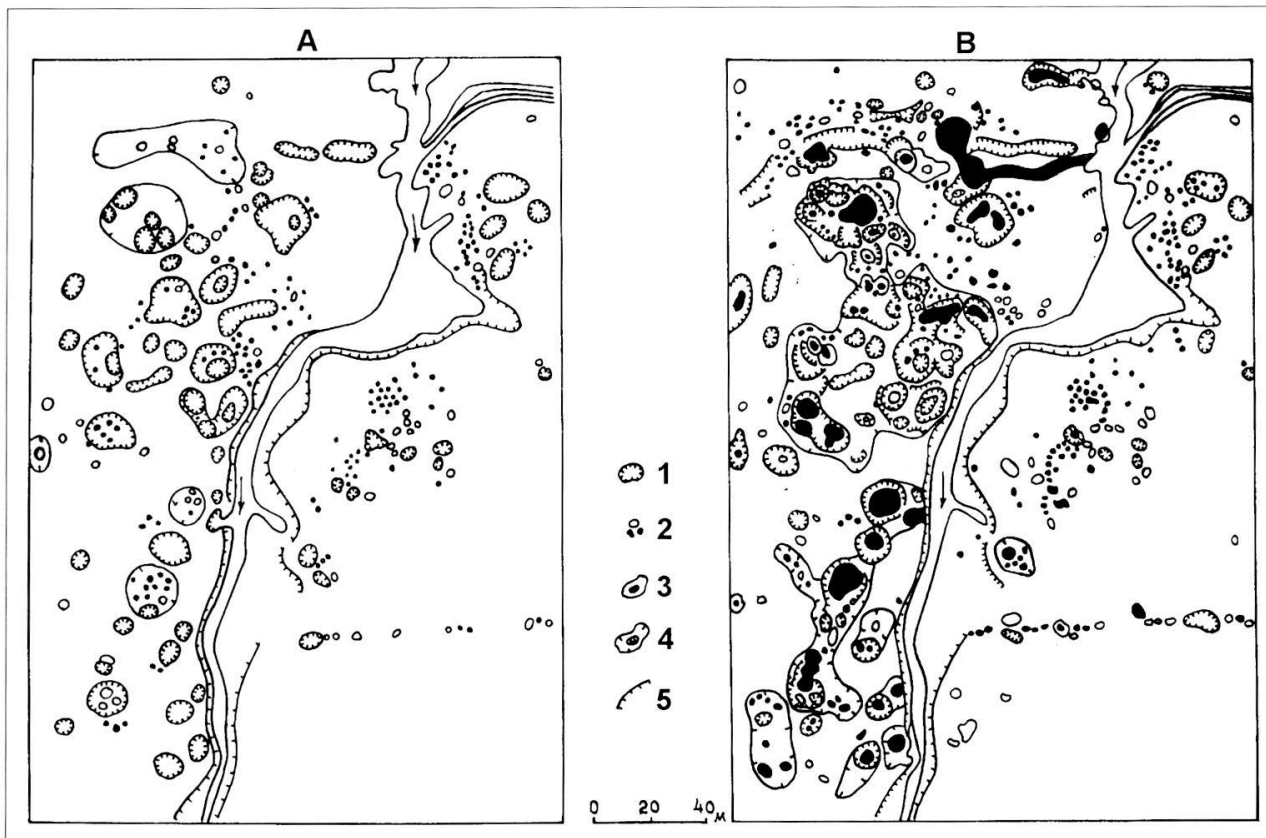

Fig. 5. Activation (A) and stabilization (B) of surface karst development induced by quarrying operations and abandonment at the quarry in the vicinity of the Nikolaevsky clay deposit. $1=$ new collapses, $2=$ small old and new (black) collapses, 3 = karst features with lakes, $4=$ old but re-activated karst features, 5 = vertical and steep ledges. 
et al, 1988; Ivanov et al, 1985). Also, washing out of unconsolidated fill has contributed to an overall increase in permeabilities.

The above processes have led to a sharp increase in collapses at the surface within extensive surrounding areas. In the vicinity of the Jazovsky deposit there were 943 collapse dolines recorded up until 1988, and of these, 260 (27.6\%) had formed during the preceding decade. Catastrophic collapse development has affected the area of the Nikolaevsky quarry as well (Fig. 5), causing severe damage to surface constructions and communications. In the latter case huge water inflows and intense collapse development eventually caused flooding and abandonment of the quarry. The potentiometric surface was established above the bottom of the clay deposits due to artesian head, and many newly-formed collapse dolines became lakes (Fig. 5-B).

\section{Construction of dams and reservoirs}

The construction of dams and reservoirs in gypsum karst areas locally increases hydraulic gradients and raises a water table in previously unsaturated rocks. Both effects can lead to enhanced dissolution if gypsum rocks occur at the foundation of a dam construction or within the zone of influence of a reservoir. This can lead to leakage from a reservoir and cause collapses affecting dams and/or the areas surrounding reservoirs. The relevant practices and hazards, and the methods of their assessment, are reviewed in James \& Lupton (1978), James (1992) and Pechorkin (1969). As dissolution of gypsum is much faster than that of limestones, these problems are potentially more severe in gypsum karst than in carbonate karst terrains.

There are numerous examples of dam failure and reservoir leakage due to accelerated development of gypsum karst in many countries. The most infamous failure associated with gypsum was in California, USA, where the St Francis Dam failed in 1928, at the cost of more than 400 lives and millions of dollars (Hill et al., 1929, cited by James, 1992). The problem was associated with dissolution of gypsum that was cementing and filling fissures in gypsiferous conglomerate in the dam foundations. Among other examples, the Hondo and Macmillan dams in New Mexico, USA, are of interest, as they are associated with gypsum and limestone in which very large dissolutional cavities had formed. The proposed reservoirs behind the Hondo and Macmillan dams were never impounded, as leakage was too rapid. In the latter case, huge underground dissolution channels with a capacity estimated at 50 million $\mathrm{m}^{3}$ had been reported. Emplacement of a cement-grouted cut-off in the foundations of the Red Rock Dam in Iowa, USA, required the injection of about 2800 metric tons of cement into boreholes that intercepted underlying dissolution conduits (James, 1992). The Huoshiro reservoir in China, with a capacity of 4.7 million $\mathrm{m}^{3}$, was built on a gypsumlimestone karst in Guizhou Province. After a period of water loss the reservoir eventually emptied through underground routes that connected a series of sinkholes in the reservoir floor to a resurgence point $400 \mathrm{~m}$ downstream of the dam, where up to $237 \mathrm{~L} / \mathrm{s}$ of water had been discharging (Yaoru \& Cooper, 1997). Cases of emptying of smaller reservoirs impounded above gypsiferous formations are numerous in the USA, Western Ukraine, Russia, Siberia, Iraq, China and other countries.

The effect of direct river water action on gypsum outcrops and of a water table being raised 


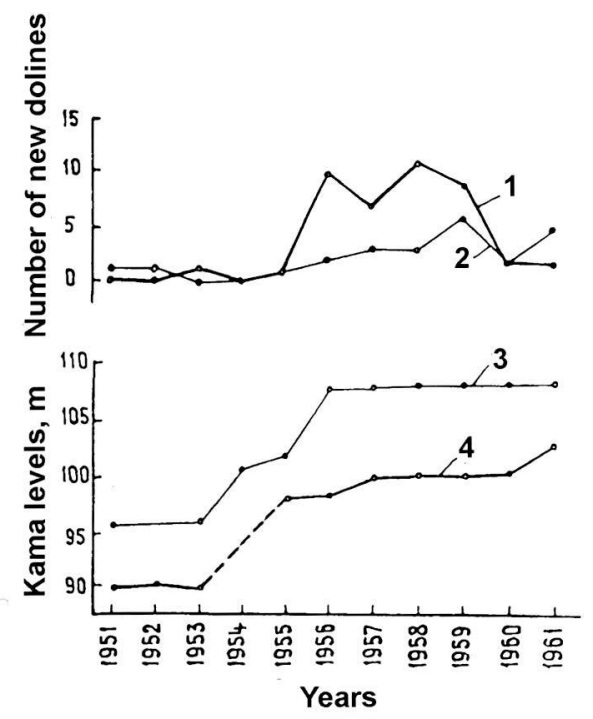

Fig.6. Dynamics of collapse processes in the coastal zone of the Kama reservoir (After Lukin et al., 1963). $1=$ collapses on the lower and middle terraces, $2=$ collapses on the high terraces, $3=$ high flow levels of water in the Kama river near Khohlovka village, $4=$ base flow levels at the same site.

within a gypsum sequence due to dam construction is exemplified by the Kama reservoir, created on the Kama river in the Pre-Urals, Russia, where the river flows entrenched into a gypsum sequence. A rise in water level of 10-15 m upstream of the dam, caused a related elevation of the water table within the gypsum of surrounding areas. Gypsum walls along the shorelines were directly exposed to the dissolving action of the reservoir water. The widening of open fissures in the gypsum outcrops during navigation season was measured, depending upon their orientation relative to flow, to vary from $0.2-0.4$ to $2.5-3.0 \mathrm{~m}$. Five year long observations of particular gypsum boulders submerged in a small gulf, have shown dissolution rates varying from 0.5 to $1.2 \mathrm{~kg} \mathrm{day}^{-1}$ m-2 (Pechorkin, 1986). Inside the gypsum massif, most active dissolution takes place within the fluctuation zone of the water table, which responds to a 5-7m seasonal change in the reservoir water level. Gypsum karst development has been greatly enhanced within 1 to $3 \mathrm{~km}$-wide zone along the reservoir coasts, resulting, particularly, in the formation of new collapses (Fig.6) and presenting severe land-use problems (Lukin et al, 1963; Gorbunova et al, 1992).

\section{Collapse and subsidence hazards}

Problems related to collapse and subsidence can be severe in intrastratal karst settings. They are recorded to cause widespread damage to various kinds of constructions, communication routes and other property, and even to cause loss of life. The extensive literature relating to subsidence includes hundreds of publications concerning gypsum karst. Mechanisms of breakdown propagation through an overburden, and the characteristics of collapse dolines in typical gypsum karst regions, are considered in Chapter I.10. Both the density and a rate of appearance of new collapses can be high in gypsum karsts. The problem is further complicated because collapse processes in gypsum karst can be greatly enhanced in response to human impacts, particularly in cases 
when such impacts modify a natural groundwater circulation pattern. This type of interaction is well illustrated in section 5 above.

\section{References}

ANDRAJCHOUK, V.N \& KLIMCHOUK, A.B. 1993. Environmental change and human impact on karst in the Western Ukraine. - In: Environmental change and human impact in karst terrains: P. W. WILLIAMS (ed.). Catena Suppl. 25, Cremlimgen. 147-160.

GORBUNOVA, K.A., ANDREJCHUK, V.N., KOSTAREV, V.P., MAXIMOVICH, N.G. 1992. Karst and caves of the Permsky region. Perm: Perm University Publ. 200 pp. (in Russian).

IVANOV, B.N. et al. 1985. Conditions and factors of technogenous activization of karst processes. In: (I.L.SOKOLOVSKIJ \& A.B.KLIMCHOUK, eds.): Fizycheskaja Geographija i Geomorphologija, vol.32. Karst of the Ukraine. Kiev: Vyshcha shkola. 47-54. (in Russian).

JAMES, A.N. 1992. Soluble materials in civil engineering. Chichester: Ellis Horwood. 435 p.

JAMES, A.N. \& LUPTON, A.R.R. 1978. Gypsum and anhydrite in foundations of hydraulic structures. Geotechnique, 3. 249-272.

KLIMCHOUK, A.B. 1997. The role of speleogenesis in the Miocene gypsum in the Western Ukraine in groundwater circulation in the multi-storey artesian system. In: (G.GUNAY \& I.JOHNSON, eds.): Karst Waters \& Environmental Impacts. Rotterdam: A.A.Balkema Publ. 281-292.

KLIMCHOUK, A.B., AKSEM, S.D., SHESTOPALOV, V.N. \& RUD'KO, G.I. 1988. The regime study of gypsum karst activity in the Western Ukraine. Kiev: Inst. Geol. Nauk. 55 pp. (in Russian).

LUKIN, V.S., LAPTEV, N.H. \& SHANGIN, JU.I. 1963. The study of collapse phenomena on the karstified coasts of Kama reservoir. Razvedka i Ochrana Nedr 12. Moscow. (in Russian).

LYSENIN, G.P. \& SOSNOVSKAYA, G.D. 1974. Flooding of the Izhemsky gypsum mine in the Komi ASSR. In: Gidrogeologija I Karstovedenije, vyp. 5. Perm: Perm University Publ. (in Russian).

PECHORKIN, I.A. 1969. Geodynamics of coasts of the Kama reservoirs. Part II. Perm. Perm University Publ. (in Russian).

PECHORKIN, A.I. 1986. Geodinamics of sulphate karst. Irkutsk: Irkutsk University Publ. 172 p. (in Russian).

VOLKOV, S.N., ANDREJCHUK, V.N. \& JANCHUK, E.A. 1987. Modern iron-manganese formations of the Zolushka Cave. In: Mineralogicheskij Sbornik 4 (1). Lvov: Lvov University. 79-83. (in Russian).

YAORU, L. \& COOPER, A.H. 1997. Gypsum karst geohazards in China. In: (BECK, F.B., Ed.): Proceedings of the sixth multidisciplinary conference on sinkholes and the engineering and environmental impacts of karst Springfield/Missouri/6-9 April 1997. To be published by A.A.Balkema, Rotterdam. 10pp. (in press). 